\title{
Evaluasi Konversi Sputum dan Faktor Korelasinya pada Pasien Tuberkulosis Paru Kategori I dengan Diabetes Melitus
}

Oki Nugraha Putra*, Hardiyono, Eka Diah Putri Pitaloka

Departemen Farmasi Klinik, Program Studi Farmasi, Universitas Hang Tuah, Surabaya, Indonesia

*Corresponding author: oki.nugraha@ hangtuah.ac.id

Submitted: 14 Mei 2020

Accepted: 26 Agustus 2020

Published: 27 April 2021

\begin{abstract}
Background: The prevalence of pulmonary TB increases in population of diabetes mellitus (DM). DM patients are higher risk for TB disease. It is suspected that in TB patients with DM, the failure rate of sputum conversion is greater than in TB without DM. Sputum conversion is an important indicator for evaluating the success of TB therapy. Objective: This study aims to evaluate the sputum conversion during 6 months of treatment with antituberculosis drugs as well as the factors that correlate to sputum conversion. Methods: This was a retrospective cohort study of category I pulmonary TB with DM with positive initial smear from 2017 to 2019. Data were collected from November 2019 to February 2020 in several health primary center in Surabaya. Results: There were 60 pulmonary TB with DM. There was a sputum conversion at the advanced phase of $96.6 \%$. About $53 \%$ of patients fall into the normal BMI category and $37 \%$ of patients with a positive initial smear $1(+1)$. Body mass index (BMI) and the positivity level of initial acid fast bacilli (AFB) were significant factors related to sputum by Kendal-Tau test $(P=0.000)$, while sex was not. Another result was success rate of $96.6 \%$ and a cure rate of $86.6 \%$. Conclusion: The conclusion of this study is that in TB patients with DM, there is no delay in sputum conversion during six months of treatment with first-line antituberculosis drugs with a percentage of sputum conversion of $96.6 \%$ at the end of the advanced phase.
\end{abstract}

Keywords: pulmonary Tuberculosis, DM, sputum conversion, BMI, initial AFB

\begin{abstract}
Abstrak
Pendahuluan: Prevalensi tuberkulosis (TB) paru meningkat seiring dengan meningkatnya populasi pasien diabetes melitus (DM). Pasien DM lebih berisiko untuk terkena penyakit TB. Diduga pada pasien TB dengan DM, tingkat kegagalan konversi sputum lebih besar dibandingkan dengan pasien TB tanpa DM. Konversi sputum merupakan indikator penting untuk mengevaluasi keberhasilan terapi TB. Tujuan: Penelitian ini bertujuan untuk mengevaluasi keberhasilan konversi sputum selama pengobatan 6 bulan dengan obat antituberkulosis (OAT) serta faktor-faktor yang berkorelasi dengan konversi sputum. Metode: Penelitian ini ialah studi observasional analitik dengan desain cohort retrospektif menggunakan lembar catatan pengobatan pasien TB kategori I dengan DM BTA awal positif pada tahun 2017 hingga 2020. Data dikumpulkan mulai November 2019 hingga Februari 2020 di beberapa Puskesmas di Surabaya. Hasil: Didapatkan 60 pasien TB kategori I yang memenuhi kriteria inklusi. Setelah pemberian OAT selama 6 bulan, terjadi konversi sputum atau conversion rate di akhir fase lanjutan sebesar 96,6\%. Sebesar 53\% pasien masuk dalam kategori BMI normal dan 37\% pasien dengan BTA awal positif $1(+1)$. Body mass index (BMI) dan tingkat kepositifan BTA awal merupakan faktor signifikan yang berhubungan dengan konversi sputum di akhir fase lanjutan $(\mathrm{P}=$ $0,000)$, sementara jenis kelamin tidak berhubungan dengan konversi sputum. Hasil lainnya ialah diperoleh success rate sebesar 96,6\% dan cure rate sebesar 86,6\%. Kesimpulan: Pada penelitian ini dapat disimpulkan
\end{abstract}


bahwa pasien TB dengan DM tidak ditemukan adanya keterlambatan konversi sputum selama enam bulan pengobatan dengan OAT lini pertama dengan persentase konversi sputum sebesar 96,6\% di akhir fase lanjutan.

Kata kunci: TB paru, DM, konversi sputum, BMI, BTA awal

\section{PENDAHULUAN}

Tuberkulosis (TB) merupakan penyakit menular yang disebabkan oleh bakteri Mycobacterium tuberculosis yang juga dikenal sebagai Basil Tahan Asam atau BTA (Kemenkes RI, 2018). Salah satu faktor risiko untuk perkembangan maupun perburukan penyakit TB adalah Diabetes Melitus (DM). Diabetes melitus ialah suatu sindrom metabolik yang ditandai oleh gangguan metabolisme karbohidrat, lemak, dan protein (PERKENI, 2015). Prevalensi penyakit TB meningkat seiring dengan peningkatan jumlah kasus DM dengan angka mobiditas dan mortalitas yang tinggi (Cahyadi, 2011). Beberapa literatur menunjukkan bahwa penderita DM berisiko untuk berkembang menjadi TB paru hingga 8,9 kali lebih besar dibandingkan pasien TB tanpa DM. Prevalensi DM pada pasien TB paru berkisar antara 5,4\% hingga 44,0\% (Mihardja dkk., 2015). Penelitian oleh Wijayanto (2013) menyebutkan bahwa prevalensi TB pada pasien DM tipe 2 sebesar $28,2 \%$ di RSUP Persahabatan, Jakarta.

Diabetes melitus merupakan salah satu faktor risiko penyakit TB. Jika dilakukan pemeriksaan sputum dan didapatkan hasil BTA positif, maka diduga waktu konversi sputum dari BTA positif menjadi BTA negatif menjadi lebih lama dibandingkan dengan pasien TB tanpa DM yang berdampak pada peningkatkan risiko penularan serta risiko timbulnya multi drug resistant tuberkulosis (MDR-TB) (Wulandari \& Sugiri, 2013). Waktu pengobatan TB paru yang lama juga berkontribusi terhadap risiko tidak tercapainya goal therapy dari pengobatan TB (Kemenkes RI, 2014). Sejumlah studi menyebutkan bahwa pasien baru TB paru dengan DM yang memiliki tingkat kepositifan BTA pada fase intensif yang tinggi akan cenderung mengalami terlambat konversi hingga pada akhir fase lanjutan (Dooley dkk., 2009). Pada pasien TB dengan DM terjadi perpanjangan waktu konversi sputum, dari BTA positif ke negatif menjadi lebih lama. Pada pasien TB tanpa DM konversi sputum dapat terjadi di akhir fase intensif atau pada bulan ke dua hingga ke tiga, akan tetapi pada pasien TB dengan DM waktu konversinya akan menjadi lebih lama yaitu pada bulan ke $4-6$. Semakin lama terjadinya konversi sputum akan berdampak terhadap lama terapi pasien TB (Baker dkk., 2011).

Angka konversi atau conversion rate adalah suatu parameter atau indikator yang dipakai untuk memantau perkembangan dan keberhasilan terapi TB. Angka ini bermanfaat untuk mengevaluasi dengan cepat dan akurat hasil pengobatan dan untuk menilai efektifitas Pengawas Menelan Obat (PMO) (Kemenkes RI, 2011). Studi terkait konversi sputum pada pasien TB dengan DM dan faktor-faktor yang mempengaruhinya telah dilaporkan di Indonesia. Akan tetapi, studi tersebut mengevaluasi konversi sputum pada akhir fase intensif, mengingat lamanya waktu pengobatan TB dengan DM, berkisar 6 sampai 8 bulan. Oleh karena itu pada penelitian ini dilakukan evaluasi konversi sputum pada pasien TB dengan DM hingga pada akhir fase lanjutan dan mengevaluasi variabel lain yang berkorelasi terhadap konversi sputum pada akhir fase lanjutan.

\section{METODE}

Penelitian ini ialah studi observasional dengan jenis penelitian cohort retrospektif yang mengevaluasi Basil Tahan Asam (BTA) pada pasien TB paru kategori I dengan DM setelah enam bulan pengobatan dengan obat antituberkulosis (OAT). Sumber data yang digunakan pada penelitian ini ialah data sekunder berupa buku atau lembar registrasi pasien TB paru kategori I dengan DM yang ditandai dengan adanya pemeriksaan BTA pada awal pengobatan, fase intensif dan akhir fase lanjutan. Data lembar catatan riwayat pengobatan yang digunakan diambil pada periode Januari 2017 sampai Februari 2020. Data yang dikumpulkan pada penelitian ini ialah BTA awal sebelum pengobatan, BTA pada akhir fase intensif dan fase lanjutan, usia, tinggi badan dan berat badan pasien, profil dan dosis OAT serta profil pengobatan untuk penyakit DM. Selain itu pula, dilakukan perhitungan conversion rate, cure rate dan success rate. Untuk Conversion Rate dihitung sebagai berikut: 
$\frac{\text { Jumlah pasien TBC BTA positif yang konversi }}{\text { Jumlah pasie TBC BTA positif yang diobati }} \times 100 \%$

Untuk Succes Rate dihitung sebagai berikut:

$\frac{\text { Jumlah pasien TBC BTA positif (sembuh }+ \text { pengobata lengkap) }}{\text { Jumlah pasie TBC BTA positif yang diobati }} \times 100 \%$

Untuk Cure Rate dihitung sebagai berikut:

$\frac{\text { Jumlah pasien TBC BT A positif yang sembuh }}{\text { Jumlah pasie TBC BTA positif yang diobati }} \times 100 \%$

Kriteria inklusi pada penelitian ini ialah pasien TB paru kategori I (diberikan untuk pasien baru dengan BTA positif dan pasien yang belum pernah diobati dengan OAT atau sudah mendapatkan OAT kurang dari 4 minggu) dengan DM yang ditandai dengan pemeriksaan awal BTA positif (+), adanya hasil pemeriksaan BTA di akhir fase intensif dan lanjutan serta usia pasien $18-70$ tahun. Kriteria eksklusi yakni catatan rekam medik yang tidak lengkap yang bisa disebabkan oleh pasien tidak rutin kontrol, pasien pindah atau pindah ke layanan fasilitas kesehatan lain maupun pasien meninggal dunia selama pengobatan TB kategori I; pasien TB dengan HIV dan TB ekstra paru. Besar sampel yang digunakan ialah seluruh pasien TB paru dengan DM yang memenuhi kriteria inklusi berdasarkan catatan pengobatan pasien. Penelitian ini dilakukan di Puskesmas Perak Timur, Puskesmas Wonokusumo, Puskesmas Tanah Kalikedinding, Puskesmas Gading, dan Puskesmas Sawah Pulo Surabaya pada bulan Desember 2019 - Februari 2020.

Pasien TB dikatakan sembuh jika pasien telah menyelesaikan terapinya secara lengkap serta pemeriksaan ulang sputum (follow-up) hasilnya negatif pada akhir pengobatan serta setidaknya satu pemeriksaan follow-up sebelumnya hasil BTA negatif. Sementara itu pengobatan dikatakan lengkap jika pasien yang telah menuntaskan terapinya secara lengkap, akan tetapi tidak memenuhi persyaratan sembuh maupun gagal. Data utama (primary outcome) yang didapatkan pada penelitian ini yakni data ordinal yaitu berupa data BTA pasien yang diuji statistik dengan uji chi-square. Untuk melihat apakah ada korelasi antara variable independent terhadap konversi sputum di akhir fase lanjutan, maka dilakukan uji korelasi Kendal-Tau. Hasil uji statistik dinyatakan bermakna apabila nilai alfa $\leq 0,05$.

\section{HASIL DAN PEMBAHASAN}

Dari hasil penelitian yang telah dilakukan, didapatkan 60 pasien TB dengan DM yang memenuhi kriteria inklusi dan datanya dinyatakan lengkap. Data demografi pasien pada penelitian ini seperti ditunjukan pada Tabel 1. Seluruh pasien pada penelitian ini mendapatkan terapi OAT dalam bentuk fix dose combination (FDC) HRZE selama 2 bulan, kemudian $\mathrm{H}_{3} \mathrm{R}_{3}$ selama 4 bulan yang semuanya termasuk tepat dosis (Depkes RI, 2005). Profil penggunaan OAT pada penelitian ini seperti ditunjukkan pada Tabel 2. Hasil pemeriksaan basil tahan asam (BTA) sebelum pengobatan, pada akhir fase intensif dan lanjutan seperti ditunjukan pada Tabel 3. Untuk melihat apakah ada korelasi antara jenis kelamin, BTA awal serta BMI terhadap konversi sputum, maka dilakukan uji korelasi Kendal-tau seperti pada Tabel 4. Pada Tabel 4 menunjukan bahwa variabel BTA awal dan BMI yang memiliki hubungan yang signifikan dengan BTA akhir $(<0,05)$, sedangkan jenis kelamin tidak memiliki hubungan dengan BTA akhir. Hasil Conversion Rate, Succes Rate dan Cure Rate pada penelitian ini seperti ditunjukkan pada Tabel 5. 
Tabel 1. Data demografi pasien TB kategori I dengan DM

\begin{tabular}{|c|c|c|}
\hline Variabel & $(n=60)$ & P value \\
\hline Jenis Kelamin, n (\%) & & $0,245^{*}$ \\
\hline Laki-laki & $35(58 \%)$ & \\
\hline Perempuan & $25(42 \%)$ & \\
\hline \multicolumn{3}{|l|}{ Umur } \\
\hline Rentang (tahun) & $46-68$ & \\
\hline$($ Mean $\pm S D)$ tahun & $52,4 \pm 7,2$ & \\
\hline Berat Badan (Mean \pm SD) $\mathrm{Kg}$ & $52,8 \pm 10,7$ & \\
\hline Tinggi Badan $($ Mean \pm SD) $\mathbf{m}$ & $1,5 \pm 0,7$ & \\
\hline Body Mass Index (BMI) $\left(\mathrm{Kg} / \mathrm{m}^{2}\right)$ & & $0,000^{* *}$ \\
\hline Underweight $(\mathrm{n}=20)$ & $16,3 \pm 1,4$ & \\
\hline Normoweight $(\mathrm{n}=32)$ & $21,7 \pm 1,5$ & \\
\hline Overweight $(\mathrm{n}=2)$ & $25,4 \pm 0,6$ & \\
\hline Obeseweight $(\mathrm{n}=6)$ & $28,2 \pm 1,4$ & \\
\hline Hasil pemeriksaan BTA awal, n (\%) & & $0,000^{* * *}$ \\
\hline (scanty 2$)$ & $3(5 \%)$ & \\
\hline$(1+)$ & $22(37 \%)$ & \\
\hline$(2+)$ & $19(32 \%)$ & \\
\hline$(3+)$ & $16(26 \%)$ & \\
\hline \multicolumn{3}{|l|}{ Profil Pengobatan DM } \\
\hline$O A D$ & 44 & \\
\hline Insulin & 16 & \\
\hline \multicolumn{3}{|l|}{ Keterangan: } \\
\hline \multicolumn{3}{|l|}{ *Binomial test } \\
\hline **One way anova test & & \\
\hline$* * *$ Mc Nemar test & & \\
\hline
\end{tabular}

Tabel 2. Profil jumlah OAT pada pasien TB paru kategori I dengan DM

\begin{tabular}{cccc}
\hline \multicolumn{2}{c}{ Jumlah OAT/ Hari } & \multirow{2}{*}{$\mathbf{6 0}(\boldsymbol{\%})$} & \multirow{2}{*}{ Berat Badan (Mean \pm SD) Kg } \\
\cline { 1 - 2 } Fase Intensif & Fase Lanjutan & & $35,7 \pm 1.5$ \\
2 tablet 4 FDC & 2 tablet 4 FDC & $4(7 \%)$ & $47,0 \pm 4.9$ \\
3 tablet 4 FDC & 3 tablet 4 FDC & $31(51 \%)$ & $60,6 \pm 5.2$ \\
4 tablet 4 FDC & 4 tablet 4 FDC & $22(37 \%)$ & $78,3 \pm 2.8$ \\
5 tablet 4 FDC & 5 tablet 4 FDC & $3(5 \%)$ & \\
\hline
\end{tabular}

Tabel 3. Hasil pemeriksaan BTA selama enam bulan pengobatan OAT

\begin{tabular}{ccccc}
\hline $\begin{array}{c}\text { Hasil BTA } \\
\text { N= 60 }\end{array}$ & $\begin{array}{c}\text { Awal } \\
\text { Pengobatan }\end{array}$ & $\begin{array}{c}\text { Akhir Fase } \\
\text { Intensif } \\
\text { (2 bulan) }\end{array}$ & $\begin{array}{c}\text { Akhir Fase } \\
\text { Lanjutan } \\
\text { (4 bulan) }\end{array}$ & P value \\
\hline (Scanty 2) & $3(5 \%)$ & $4(7 \%)$ & $1(1 \%)$ & $0,025^{*}$ \\
(Scanty 3) & - & $1(1 \%)$ & - & \\
$(\mathbf{1 + )}$ & $22(36 \%)$ & $4(7 \%)$ & - & \\
$(\mathbf{2 + )}$ & $19(32 \%)$ & $1(1 \%)$ & - & \\
$(\mathbf{3 +})$ & $16(27 \%)$ & - & $1(1 \%)$ & \\
$(-)$ & - & $50(84 \%)$ & $58(98 \%)$ & \\
\hline \multicolumn{5}{c}{} \\
\hline
\end{tabular}

Keterangan:

* BTA fase intensif - BTA fase lanjutan (chi-square) 
Tabel 4. Hasil uji korelasi independent variable terhadap konversi sputum BTA

\begin{tabular}{lcc}
\hline Variabel & R & P value \\
\hline BTA awal & $-0,809$ & 0,000 \\
BMI & 0,473 & 0,000 \\
Jenis Kelamin & 0,220 & 0,091 \\
\hline
\end{tabular}

Tabel 5. Hasil conversion rate, success rate dan cure rate

\begin{tabular}{cccc}
\hline \multicolumn{2}{c}{ Conversion Rate } & Succes Rate & Cure Rate \\
\cline { 1 - 1 } Intensif & Lanjutan & & \\
\hline $83,3 \%$ & $96,6 \%$ & $96,6 \%$ & $86,6 \%$ \\
\hline
\end{tabular}

Telah dilakukan penelitian yang mengevaluasi basil tahan asam (BTA) selama 6 bulan pengobatan dengan obat antituberkulosis (OAT) pada pasien TB kategori I dengan DM. Pada penelitian ini diperoleh 60 pasien TB kategori I dengan DM yang memenuhi kriteria inklusi. Hasil studi ini menunjukkan bahwa proporsi pria lebih banyak (58\%) dibandingkan dengan perempuan. Hal ini sejalan dengan penelitian oleh Nadliroh dkk. (2015), yang menyatakan bahwa pasien TB dengan DM rawat jalan di RSUP Dr. Kariadi Semarang, didapatkan bahwa pria lebih banyak terkena TB dengan DM sebesar 58,5\% dibandingkan dengan perempuan. Penelitian oleh Alisjahbana dkk. (2007) juga mendapatkan hasil bahwa proporsi pasien TB dengan DM yang berjenis kelamin laki-laki lebih besar (52\%) dibandingkan dengan perempuan.

Prevalensi TB lebih besar dialami oleh laki-laki daripada perempuan, dikarenakan laki-laki memiliki kebiasaan merokok yang jauh lebih tinggi daripada perempuan. Merokok dapat menurunkan sistem imun tubuh sehingga lebih rentan terpapar bakteri TB dan ketika dilakukan pemeriksaan dahak menunjukkan hasil BTA positif (Kemenkes RI, 2013). Selain itu pada perempuan terdapat hormon steroid dan estradiol yang dapat mengaktifkan makrofag serta menghasilkan lebih banyak interferon-gamma (IFN- $\gamma$ ) yang berperan sebagai imunitas alamiah tubuh (Callippe dkk., 2008).

Pada penelitian ini, didapatkan usia rata-rata pasien ialah 52,4 $\pm 7,2$ tahun. Penelitian oleh Towhidi, menyebutkan bahwa prevalensi DM lebih banyak pada pasien tuberkulosis pada umur lebih dari 45 tahun. (Towhidi dkk., 2008). Penelitian oleh Kulsum dkk. (2017), melaporkan bahwa median umur pasien TB dengan DM ialah 53,7 tahun. Penelitian lain oleh Wijayanto dkk. (2015) juga didapatkan rata-rata usia pasien TB dengan DM ialah 58,6 tahun. Penelitian oleh Alisjahbana juga melaporkan median usia pasien TB dengan DM lebih besar daripada pasien TB tanpa DM, yakni 45 tahun dan 27 tahun secara berturut-turut (Alisjahbana dkk., 2007). Hal ini dikarenakan pada pasien lanjut usia terjadi penurunan barrier mikroba pada sistem pernafasan. Kondisi hiperglikemia yang tidak terkontrol juga akan mengganggu imunitas tubuh sehingga menjadi penyebab tingginya prevalensi TB pada pasien DM yang lanjut usia (Nazulis, 2011).

Untuk penegakan diagnosis TB, maka dilakukan pemeriksaan dahak mikroskopis BTA. Selain untuk diagnosis, maka pemeriksaan BTA juga dilakukan untuk mengevaluasi keberhasilan terapi dengan OAT dan menetapkan risiko kemungkinn potensi penularan (Depkes RI, 2005). Pada penelitian ini, BTA awal pasien atau initial load secara signifikan paling banyak ialah positif $1(+1)$ sebesar $37 \%$. Hal ini sesuai dengan penelitian oleh Jiyani dkk. (2015), yang menyatakan bahwa gambaran awal sputum pasien tuberkulosis dengan DM terbanyak yaitu +1 sebesar $44 \%$. Semakin besar tingkat kepositifan BTA awal, akan menyebabkan waktu konversi sputum yang lebih lama. Penelitian oleh Nissapatorn dkk. (2005), juga melaporkan hasil bahwa semakin besar nilai BTA awal sebelum pengobatan memiliki hubungan yang signifikan dengan waktu konversi sputum yang lebih lama.

Pada penelitian ini, terdapat perbedaan bermakna body mass index (BMI) pada awal pengobatan. Sebesar 53\% pasien TB dengan DM berada pada BMI normoweight dengan rata-rata $21,7 \pm 1,5 \mathrm{Kg} / \mathrm{m}^{2}$. Hal ini sesuai dengan penelitian oleh Amare dkk. (2013) yang juga menyatakan pada pasien tuberkulosis disertai DM pada fase lanjutan mayoritas mempunyai BMI normoweight, sedangkan pada pasien tuberkulosis tanpa DM cenderung mempunyai BMI underweight. Peningkatan BMI dengan bertambahnya usia merupakan salah satu faktor untuk terjadinya DM (Amare dkk., 2013).

Penelitian oleh Mega dkk. (2019) menyebutkan bahwa terdapat hubungan yang signifikan antara body mass index (BMI) dengan konversi sputum serta terdapat hubungan yang bermakna antara body mass index dengan kadar albumin pada pasien TB paru. Pasien dengan BMI yang normal memiliki kadar 
albumin di atas 3,5 g/dL sebanyak 66\% (Mega dkk., 2019). Albumin ialah salah satu protein darah, dimana ketika terjadi suatu infeksi berkepanjangan, maka terjadi proses katabolisme protein untuk memperbaiki sel dan jaringan rusak akibat infeksi, membentuk imunitas tubuh serta untuk menetralisir radikal bebas. Jika kondisi tersebut berlangsung berkepanjangan, maka terjadi penurunan albumin plasma atau hipoalbumin. Selain itu pula, nafsu makan yang menurun akibat salah satu efek samping OAT, kondisi malnutrisi dan malabsorbsi seringkali juga ditemukan pada pasien TB yang dapat mengakibatkan hipoalbumin (Memon \& Naz, 2014).

Salah satu parameter keberhasilan TB adalah konversi sputum yang merupakan konversi BTA positif ke negatif. Konversi sputum adalah salah satu hasil terpenting dalam kasus TB paru, selain hasil klinis. Pada penelitian ini didapatkan hasil bahwa proporsi kegagalan konversi sputum pada bulan kedua di akhir fase intensif yakni 16,6\%. Alisjahbana dkk. (2007) melaporkan bahwa kegagalan konversi sputum pada akhir bulan kedua pada pasien TB dengan DM sebesar $18,1 \%$, sedangkan pasien TB tanpa DM sebesar $10 \%$. Tanpa melihat hasil BTA di akhir fase intensif apakah positif atau negatif, maka pengobatan langsung dilanjutkan ke fase lanjutan selama 4 bulan. Penelitian lain oleh Kalsum didapatkan hasil bahwa kegagalan konversi sputum yang secara signifikan lebih besar pada pasien TB dengan DM, yakni sebesar 43,0\% dibandingkan dengan pasien TB tanpa DM, 22,7\% dengan risiko relatif 1,8 . Hal ini dikarenakan penelitian oleh Kulsum dkk. (2017), menggunakan pasien yang telah terdiagnosis DM kemudian memperoleh diagnosis tambahan TB. Jika pada akhir fase intensif tidak terjadi konversi sputum, maka hal tersebut adalah salah satu prediktor terkuat untuk kegagalan terapi TB, meskipun hal tersebut bukan indikator terbaik karena nilai prediktifnya yang lemah (Kuaban dkk., 2009). Pada penelitian ini juga diamati Conversion rate, Success rate, dan Cure Rate. Conversion rate menunjukan seberapa banyak pasien TB dengan BTA positif yang terkonversi menjadi BTA negatif setelah menjalani pengobatan fase intensif maupun fase lanjutan. Success rate menunjukan banyaknya pasien baru $\mathrm{TB}$ dengan BTA positif yang telah menyelesaikan pengobatan (baik yang sembuh maupun pengobatan lengkap). Cure rate adalah banyaknya pasien TB baru dengan BTA positif yang dinyatakan sembuh setelah selesai masa terapi dengan OAT (Kemenkes RI, 2017).
Pada penelitian ini, keseluruhan pasien TB dengan DM dengan BTA awal positif, sebanyak 50 pasien terkonversi menjadi BTA negatif pada akhir fase intensif. Kemudian, 58 pasien terkonversi menjadi BTA negatif, atau naik sebesar $16 \%$ dari BTA pada akhir fase lanjutan. Hasil uji statistk dengan uji chi-square, diperoleh p-value sebesar 0,025 yang menunjukan bahwa terdapat perbedaan bermakna BTA pasien pada akhir fase intensif dan pada akhir fase lanjutan. Hal ini mengindikasikan bahwa pengobatan dengan OAT selama 6 bulan, mampu untuk menyebabkan konversi sputum secara signifikan. Conversion rate pada akhir fase intensif sebesar 83,3\%, dan pada akhir fase lanjutan mengalami kenaikan menjadi 96,6\%. Hal ini menunjukan bahwa pengobatan pasien tuberkulosis dengan DM mengalami conversion rate melebihi standar yang ditetapkan oleh Kemenkes RI, yaitu minimal conversion rate sebesar $80 \%$ (Kemenkes RI, 2011). Penelitian oleh Alisjahbana dkk. (2007), menunjukan bahwa conversion rate pada akhir fase lanjutan lebih besar daripada pada akhir fase intensif, sebesar 74,5\% dan 71,3\% secara berturut-turut. Pasien TB pada fase lanjutan selama 4 bulan, mengkonsumsi OAT hanya 2 jenis, yakni rifampisin dan isoniazid yang bertujuan untuk membunuh bakteri TB yang kemungkinan persisten atau belum sepenuhnya mati pada fase intensif, sehingga mencegah timbulnya kekambuhan (relaps) (Alisjahbana dkk., 2007). Hasil studi ini berbanding terbalik dengan hasil yang ditunjukan oleh Baker, yang mana pada pasien TB tanpa DM, konversi sputum terjadi pada bulan ke 2 - 3 atau di akhir fase intensif, sedangkan pada pasien TB dengan DM waktu konversinya baru terjadi pada bulan ke 4 - 6 (Baker dkk., 2011).

Hasil uji korelasi Kendal-Tau, didapatkan hasil bahwa variabel BTA awal dan BMI yang memiliki hubungan yang signifikan dengan BTA akhir $(<0,05)$, sedangkan jenis kelamin tidak memiliki hubungan dengan BTA akhir. Penelitian oleh Mega dkk. (2019), menunjukkan bahwa pasien TB paru dengan kategori BMI underweight $\left(<18,5 \mathrm{Kg} / \mathrm{m}^{2}\right)$ lebih banyak yang tidak mengalami konversi sputum, dibandingkan dengan BMI normoweight (> 18,5 - $25 \mathrm{Kg} / \mathrm{m}^{2}$ ) lebih banyak yang mengalami konversi sputum. Dari hasil tersebut menunjukkan bahwa salah satu hal yang cukup penting yang dapat mempengaruhi keberhasilan konversi sputum BTA pada pasien TB paru adalah status gizi awal pasien sebelum memulai terapi OAT (Mega dkk, 2019). Penelitian oleh Tama, juga menunjukkan hasil bahwa pasien TB paru dengan BTA positif pada 
awal pengobatan dengan BMI kurang daru 18,5 Kg/m² memerlukan waktu yang lebih panjang untuk terjadinya konversi sputum dan 1,32 - 8,86 kali lebih besar risiko terjadinya kegagalan konversi jika dibandingkan pasien yang memiliki BMI lebih dari 18,5 Kg/m² (Tama dkk, 2016).

Kemudian untuk Success rate didapatkan hasil sebesar 96,6\%, yang telah memenuhi standar success rate oleh Kemenkes RI, yakni minimal sebesar $90 \%$. Pada penelitian ini, didapatkan hasil bahwa sebesar 37\% pasien TB dengan DM memiliki BTA awal +1 . Pada akhir fase lanjutan ditemukan bahwa pasien dengan BTA awal +1 , semuanya mengalami konversi sputum menjadi BTA negatif yang dengan kata lain tidak terjadinya keterlambatan konversi sputum. Hasil penelitian ini sejalan dengan penelitian oleh Nwokeukwu \& Awujo (2013) yang menyebutkan bahwa pada pasien TB dengan BTA awal positif 2 dan positif 3 cenderung untuk terjadinya keterlambatan konversi sputum pada bulan ke 6 bila dibandingkan pada pasien dengan BTA awal (1+) dan scanty. Hal ini mengindikasikan bahwa semakin tinggi tingkat kepositifan BTA awal, semakin lama waktu yang diperlukan untuk konversi sputum atau dengan kata lain terjadinya keterlambatan konversi sputum (Nwokeukwu $\&$ Awujo, 2013). Kemudian untuk Cure rate didapatkan sebesar 86,6\% yang sudah memenuhi standar dari Kemenkes RI, yaitu sebesar 85\% (Kemenkes RI, 2011).

Penelitian ini memiliki beberapa keterbatasan yaitu, tidak adanya data gula darah, nilai $\mathrm{HbA1c}$, riwayat merokok, serta profil obat antidiabetes (OAD) pasien TB dengan DM yang secara tidak langsung juga dapat mempengaruhi konversi sputum. Oleh karena itu diperlukan penelitian lanjutan untuk melihat variabelvariabel tersebut terhadap konversi sputum dengan jumlah sampel yang lebih besar.

\section{KESIMPULAN}

Kesimpulan yang didapatkan pada penelitian ini ialah pada pasien TB dengan DM tidak ditemukan adanya keterlambatan konversi sputum selama enam bulan pengobatan dengan OAT lini pertama dengan persentase konversi sputum sebesar 96,6\% di akhir fase lanjutan. Saran yang dapat diberikan untuk penelitian kedepannya ialah perlu dilakukan pemeriksaan gula darah setidaknya satu kali selama pengobatan OAT terutama untuk melihat pengaruhnya terhadap konversi sputum serta dilakukan penambahan tempat pengambilan sampel agar didapatkan jumlah sampel yang lebih banyak yang dapat menggambarkan populasi pasien TB dengan DM secara keseluruhan.

\section{UCAPAN TERIMA KASIH}

Penulis menyampaikan ucapan terima kasih kepada seluruh staf di Puskesmas Perak Timur, Puskesmas Wonokusumo, Puskesmas Tanah Kalikedinding, Puskesmas Gading, dan Puskesmas Sawah Pulo Surabaya yang telah menyediakan tempat dan waktunya untuk pengambilan data penelitian.

\section{DAFTAR PUSTAKA}

Alisjahbana, B., Sahiratmadja. E., Nelwan. E. J., Purwa, A. M., Ahmad, Y. \& Ottenhoff, T. H. (2007). The Effect of Type 2 Diabetes Mellitus on the Presentation and Treatment Response of Pulmonary Tuberculosis. Clinical Infectious Diseases; 45; 428-435.

Amare, H., Gelaw, A., Anagaw, B. \& Gelaw B. (2013). Smear Positive Pulmonary Tuberculosis Among Diabetic Patients at the Dessie Refferal Hospital. Infections Disease of Poverty; 6; 90-96

Baker, M. A., Harries. A. D., Jeon. C. Y., Hart, J. E., Kapur, A., Lönnroth K., Ottmani, S. E., Goonesekera, S. D. \& Murray. M.B. (2011). The Impact of Diabetes on Tuberculosis Treatment Outcomes: A Systematic Review. $B M C$ Medicine; 9; 81.

Cahyadi. A. V. (2011). Tuberkulosis Paru pada Pasien Diabetes Melitus. Journal of the Indonesian Medical Association; 4; 174- 176

Callippe, B., Dounin-Echinard, V., Laffargue, M. \& Laurell. H. (2008). Chronic Estradiol Administration in Vivo Promotes the Proinflammatory Response of Macrophages to TLR-4 Activation: Involvement of the Phosphatidylinositol 3-Kinase Pathway. The Journal of Immunology; 180; 7980-7988

Departemen Kesehatan RI (Depkes RI). (2005). Pharmaceutical Care untuk Penyakit Tuberkulosis, Direktorat Bina Farmasi Komunitas dan Klinik. Jakarta: Departemen Kesehatan RI.

Dooley, K. E., Tang, T., Golub, J. E., Dorman, S. E. \& Cronin, W. (2009). Impact of Diabetes Mellitus on Treatment Outcomes of Patients with Active Tuberculosis. American Journal of Tropical Medicine and Hygiene; 80; 634-639.

Jiyani, M. R., Vadgama, P. K., Pandey, A. S. \& Modh, D. A. (2015). Clinical Profile and Outcome of 
Tuberculosis in Patients with Diabetes. International Journal of Research in Medical Sciences; 4; 36-40.

Kemenkes RI. (2011). Profil Kesehatan Indonesia 2010. Jakarta: Kementrian Kesehatan Indonesia RI.

Kemenkes RI. (2013). Laporan Riset Kesehatan Dasar (Riskesdas) Tahun 2013. Jakarta: Kementrian Kesehatan Indonesia RI.

Kemenkes RI. (2014). Direktorat Pengendalian Penyakit dan Penyehatan Lingkungan: Pedoman Nasional Pengendalian Tuberkulosis. Jakarta: Kementrian Kesehatan Indonesia RI

Kemenkes RI. (2017). Direktorat Pengendalian Penyakit dan Penyehatan Lingkungan. Pedoman Nasional Pengendalian Tuberkulosis. Jakarta: Kementrian Kesehatan Indonesia RI

Kemenkes RI. (2018). Pusat Data dan Informasi Kementrian Kesehatan RI. Jakarta: Kementrian Kesehatan Indonesia RI.

Kuaban, C., Bame, R., Mouangue, L., Djella, S. \& Yomgni, C. (2009). Non Conversion of Sputum Smears in New Smear Positive Pulmonary Tuberculosis Patients in Yaound'e, Cameroon. East African Medical Journal; 5; 219-225.

Kulsum, D. I., Burhan, E. \& Rochismandoko. (2017). Factors Affecting Conversion of Microscopic BTA Sputum in Lung Tuberculosis Patients New Cases with Diabetes Mellitus. Jurnal Respirologi Indonesia; 37; 109-118

Mega, J. Y., Sari. D. K. \& Harahap. J. (2019). Korelasi Indeks Massa Tubuh dan Kadar Albumin Dengan Konversi Sputum Pasien Tuberkulosis. Indonesian Journal of Human Nutrition; 6; 96109.

Memon, A. R. \& Naz, R. (2014). Protein and Albumin Level in Pulmonary Tuberculosis Sindh, Pakistan. New York Science Journal; 7; 8.

Mihardja, L., Lolong, D. B. \& Ghani, L. (2015). Prevalensi Diabetes Melitus pada Tuberkulosis dan Masalah Terapi. Journal of Health Ecology; 4; 350-358.

Nadliroh, Z., Kholis, F. N. \& Ngestiningsih, D. (2015). Prevalensi Terjadinya Tuberkulosis pada Pasien Diabetes Melitus di RSUP Dr. Kariadi Semarang. Media Medika Muda; 4; 1714-1721.
Nazulis, R. A. (2011). Drug Related Problems pada Pasien Diabetes Melitus Tipe 2 dengan Tuberkulosis Paru di Bangsal Penyakit Dalam dan Poliklinik RSUP. Dr. M. Djamil Padang. Tesis; Fakultas Farmasi Universitas Andalas, Padang.

Nissapatorn, V., Kuppusamy, I. \& Jamaiah, I., Fong, M. Y., Rohela, M. \& Anuar, A. K. (2005). Tuberculosis in Diabetic Patients: A Clinical Perspective. The Southeast Asian Journal of Tropical Medicine and Public Health; 36; 213 220.

Nwokeukwu, H. I. \& Awujo, D. N. (2013). Association of Sputum Conversion and Outcome with Initial Smear Grading Among New Smear Positive Tuberculosis Patients in A Tertiary Health Facility, South East Zone, Nigeria. Journal of Dental and Medical Sciences; 4; 4-9.

PERKENI. (2015). Konsensus Pengelolaan dan Pencegahan Diabetes Melitus Tipe 2 di Indonesia. (2015). Jakarta: Perkumpulan Endokrinologi Indonesia (PERKENI).

Tama, T. D., Adisasmita, A. C. \& Burhan, E (2016). Indeks Massa Tubuh dan Waktu Terjadinya Konversi Sputum pada Pasien TB Paru BTA Positif di RSU Persahabatan. Jurnal Epidermiologi Kesehatan Indonesia; 1; 1-8.

Towhidi, M., Azarian, A. \& Asnaashari, A. (2008). Pulmonary Tuberculosis in The Elderly. Tanaffos; 7; 52-57.

Wijayanto, A. (2013). Faktor yang Berhubungan dengan Terjadinya Tuberculosis Paru pada Pasien Diabetes Melitus Tipe 2 di RSUP Persahabatan. Tesis; Fakultas Kedokteran Universitas Indonesia, Jakarta.

Wijayanto, A., Burhan, E., Nawas, A. \& Rochsismandoko. (2015). Faktor Terjadinya Tuberkulosis Paru pada Pasien Diabetes Melitus Tipe 2. Jurnal Respirologi Indonesia; 35; 1-11.

Wulandari, D. R. \& Sugiri. Y. J. (2013). Diabetes Melitus dan Permasalahannya Pada Infeksi Tuberkulosis. Jurnal Respirologi Indonesia; 2; 32. 